\title{
Eten, een zaak van gewicht
}

Citation for published version (APA):

Westerterp-Plantenga, M. S. (2006). Eten, een zaak van gewicht. Universiteit Maastricht. https://doi.org/10.26481/spe.20061124mw

Document status and date:

Published: 24/11/2006

DOI:

10.26481/spe.20061124mw

Document Version:

Publisher's PDF, also known as Version of record

\section{Please check the document version of this publication:}

- A submitted manuscript is the version of the article upon submission and before peer-review. There can be important differences between the submitted version and the official published version of record.

People interested in the research are advised to contact the author for the final version of the publication, or visit the DOI to the publisher's website.

- The final author version and the galley proof are versions of the publication after peer review.

- The final published version features the final layout of the paper including the volume, issue and page numbers.

Link to publication

\footnotetext{
General rights rights.

- You may freely distribute the URL identifying the publication in the public portal. please follow below link for the End User Agreement:

www.umlib.nl/taverne-license

Take down policy

If you believe that this document breaches copyright please contact us at:

repository@maastrichtuniversity.nl

providing details and we will investigate your claim.
}

Copyright and moral rights for the publications made accessible in the public portal are retained by the authors and/or other copyright owners and it is a condition of accessing publications that users recognise and abide by the legal requirements associated with these

- Users may download and print one copy of any publication from the public portal for the purpose of private study or research.

- You may not further distribute the material or use it for any profit-making activity or commercial gain

If the publication is distributed under the terms of Article $25 \mathrm{fa}$ of the Dutch Copyright Act, indicated by the "Taverne" license above, 
Eten, een zaak van gewicht 


\section{Colofon}

Basicontwerp en realsatie: Oce Business Services, Universiteit Maastricht.

Whatratie omshlag: Eric Corle, wit het boek Rupse Nooitgenoeg

15 SN-10:90-568:-250-5

HSBN-13:978-90-5681-250-8

NUR 882

whe rechten voorbehouden. Niets wit deze witgove mag worden verveelvoudigd, opgeslagen in een geautomatiseerd gegevensbestand of openbaar gemalakt, zonder woorafgande schriftelijke toesternming wan de auteur of uitgever. 


\section{Eten, een zaak van gewicht}

\section{Rede}

Uitgesproken bij de aanvaarding van het Ambt wan bijzonder hoogleraar Voedselinname-regulatie bij de mens an de Faculteit der Gezondheidswetenschappen van de Universiteit Maastricht

op vrijdag 24 november 2006

door

Dr. Margriet S. Westerterp-Plantenga

\section{v}

(1) Universitelt Maastricht

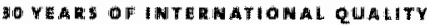



Mijnheer de Rector Magnificus, geachte toehoorders,

\section{Inleiding}

Eten is een worm van gedrag, die evenals het meeste gedrag oorzaak, ontwikkeling, funktie, en evolutie kent. De oorzaak van dit gedrag wordt gevormd door fysiologische mechanismen die informatie van buiten en vanuit het lichaam verwerken, en in gedrag tot uiting brengen. De genetische achtergrond van het individu, als ook ontwikkelingen in de loop van ieders leven, bijvoorbeeld door middel van leerprocessen, spelen hierbij een rol.

De funktie van dit gedrag houdt verband met de vraag naar de overlevingswaarde ervan. Waarop meteen de vraag volgt: op welke wijze heeft het gedrag in de loop wan de evolutie zijn vorm gekregen?

De voedselinname-regulatie bij de mens beweegt zich op het terrein van oorzaak, ontwikkeling, funktie en evolutie van het voedselinname gedrag, of wel het eten.

\section{Oorzaak van gedrag}

Het zien, ruiken en proeven van woedsel draagt bij aan de beslissing van het individu of deze daadwerkelijk zal gaan eten of niet. Toetsing aan de energiebehoefte is de volgende stap. Deze toetsing vindt plaats via de noemer van honger en verzadiging (1). Aan hongergevoelens, zoals die in de hersenen tot uiting komen, dragen bepaalde signalen uit het lichaam bij zoals de concentratie van glucose en van hormonen irn het bloed, en het signaal van de rekreceptoren in de maag (2). Zo leidt een dip in de glucose-concentratie en een piek in de concentratie van het hormoon ghreline meestal tot voedselinname (3.4). Aan verzadigingsgevoelens dragen in eerste instantie het ruiken en proeven van het voedsel bij. Het proeven zonder te eten geeft een kortdurend verzadigend effect en heeft effect op de stofwrisseling (5). Vervolgens leidt voedselinname tot werhoogde concentraties van glucose en van hormonen zoals insuline. glucagon-like peptide-1, polypeptide-y en cholecystokinime in het bloed $(2,6,7)$. Dergelijke hormonen worden geproduceerd in het maagdarmkanaal, tijdens en na het eten. Het voedsel wordt verder verwerkt, en met behulp van zuurstof geoxideerd, waarbij met name vanuit de lever opnieuw verzadigingssignalen naar de hersemen gaan $(8,9)$. Honger- en verzadigingssignalen zijn echter niet alleen bepalend voor de woedselinnameregulatie. Ook de belonende waarde wan de voedselinname speelt een belangrijke rol; daar kom ik later op terug. 


\section{Ontwikkeling van gedrag}

Naast toetsing aan de lichamelijke conditie die de energetische homeostase weergeeft, wordt de beslissing: wel of niet eten getoetst aan ervaringen. Ervaringen met de smalak, kwaliteit en energiedichtheid van het aangeboden voedsel verstrekken een inschatting van het verwachte verzadigende en belonende effect wan thet woedsel (1).

Dan speelt de situatie een rol: is tijd en plaats van toepassing, is eten op dat moment emotioneel gezien van toepassing?

\section{Modullerende effecten}

Effecten van het dag-nacht ritme, de omgevingsternperatuur, de lichamelijke aktiviteit, en bijvoorbeeld werbliff op grote hoogte moduleren de reaktie van het individu op het voedselaanbod $(3,10-15)$.

\section{Integratle}

Integratie van oorzaak, ontwikkeling en modulatie van gedrag leidt in een flits van een seconde tot de beslissing om motor-zenuwcellen te aktiveren of niet en aldus start of stopt de voedsel-inname en selectie. Dit is een zich herhalend proces, dat meestal onbewust verloopt en in gewoontevorming resulteert (1). Onderzoek aan oorzaak, ontwikkeling en modulatie van voedselinname gedrag geeft inzicht in de mogelijkheden orn dit gedrag desgewenst te beinvloeden.

Intermezzo 1: Ontwikkeling van gedrag

verschillende voedingssstoffen blijken een verschillend verzadigend effect te hebben. Alcohol is het minst verzadigend per kilojoule; dan volgen respectievelijk vet, koolhydraat en eiwit $(16,17)$. Alcohol is het minst verzadigend; het stimuleert in feite de voedselinname. Tot nut toe is het verschijnsel dat men zich na allcohol consumptie licht in het hoofd voelt de enige samenhang die aangetoond is met de geringe verzadiging; de beheersing van de voedselinname is verminderd en men probeert dat lichte gevoel als het ware 'weg te eten' (16).

De geringe verzadiging van vet per kilojoule wordt gedeeltelijk veroorzaakt door de hoge energiedichtheid, het levert per gram twee keer zoveel energie als koolhydraat of eiwit. Een andere oorzalk is de alantrekkelijkheid van vette voeding; vet gecombineerd met zoet of hartig wordt door de meeste mensen als lekker ervaren. Vet vormt een coating in de 
mond die de smaak van de andere maaltijd-componenten verzacht. Ook vet blijkt in eerste instantie de woedselinname te stimuleren in plaats van te remmen, mede doordat het traag wordt verteerd, en als laatste van de macronutrienten wordt geoxideerd. Met name bij de vetoxidatie worden opnieuw verzadigingsssignalen naar de hersenen gezonden. Echter bij de vetinname komt dit vaak als mosterd na de maaltijd; doordat de verzadigingssignalen zo laat na een maaltijd optreden is er waak al weer iets geconsumeerd voordat ze benut kunnen worden $(3,8,9,18,79)$.

Koolhydraat geeft snel een verzadigingssignaal. Maar ook ontstaat snel weer honger (3). Eiwit ten slotte is het meest verzadigend (17).

De zogenoemde verzadigingshormonen reageren specifiek op deze voedingsstofffen: zo is na een koolhydraat- of eiwitrijke maaltijd de Gi.P-1 concentratie vooral verhoogd, terwijl na een vetrijke maaltijd de cholecystokinine concentratle vooral verhoogd is $(2,46)$. Ervaring met verschillende voedingsimiddelen leert dat men het specifieke verzadigende effect van een voedingsmiddel kan inschatten.

\section{Ontwikkeling van gedrag: inschatten van de energie-dichtheid}

Doordat verschillende vaedingsistoffen een verschillende energiedichtheid, dwz een verschillend aantal killojoules per gram hebben. hangt de energie die men binnen krijgt af van het soort voedsel dat men eet \{20\}. En die energie, daar gaat het om, gezien de uiteindelijke balans. Een maaltijd bestaat meestal uit een mengsel van koolhydraat, eiwit en vet, en heeft daardoor een specifieke energiedichtheid. Individuele inschatting daarvan is van belang om de grootte van de portie die men opschept en meestal ook opeet, te kunnen bepalen.

Uit een onderzoek bij vrouwen bleek dat zij die een normaal gewicht hebben grote porties eten van laag energiedicht voedsel, zoals groente en fruit, middelmatige porties van middelmatig energiedicht voedsel, zoals brood, aardappelen, rijst, pasta, en kleine porties van zeer energiedicht voedsel zoals pizza, cake, kaas, chocola, evenals de richtlijnen aangeven (20.22). vrouwen met overgewicht darentegen nemen naast middelmatige porties van middelmatig energiedicht voedsel, kleinere porties van laag energiedicht voedsel en grotere porties van hoog energiedicht woedsel. Dit is voor hen een manier om op overgewicht te blijven: daartoe moet een aanzienlijke hoeveelheid energie per dag worden geconsumeerd (20-22).

Dat inschattting van energiedichtheid succesvol wordt aangeleerd blijkt uit cultureel bepaalde. geciviliseerde standaard portiegroottes, die men ook in recepten aantreft. Gaat men uit eten, en wordt men 
geconfronteerd met en onbekend recept, dan wordt het inschatten van de energiedichtheid lastiger; in dit opzicht lijdt het geen twijfel dat "nouvelle cuisine' de voorkeur heeft boven amerikanisering.

Binnen een maaltijd bereid volgens onbekend recept blijkt de besissing om te stoppen met eten afgeleid te worden uit het gewicht dat men gegeten heeft met als gevolg hoe groter de energiedichtheid, hoe meer energie men binnen krijgt (23).

Op lange termijn blijkt men hiervoor inderdaad via portiegrootte te corrigeren. Onderzoek wees uit dat zogeheten ongeremde eters, $d w z$ zij die onbewust eten wat ze willen eten, corrigeren woor te lage energiedichtheden; zij gaan van een laag energiedicht menu na verloop van tijd meer eten, waardoor zij op gewicht blijven. Geremde eters, dwz zij] die bewust eten wat ze zichzelf toestaan, corrigeren woor hoge energiedichtheden: na verloop van enige tijd eten ze minder van eem energiedicht menu, en blijwen ook in dergelijke overgewicht-bevorderende omstandigheden op gewicht (24).

\section{Ontwikkeling van gedrag: maaltijdfrequentie}

Naast de hoeveelheid die men tijdens de maaltijd eet, speelt de maaltijdfrequentie een rol. Bij jonge gezonde slanke mannen is aangetoond dat zij hun energieinname nauwkeurig kunnen koppelen aan hun energiegebrulk door middel van frequente consumptie van koolhydraatrijke, vetarme maaltijden. Zij maken gebruik van de snelle afwisseling tussen verzadiging en honger die deze maaltijden kenmerken, en voldoen aian hun energiebehoefte door middel van consumptie van veel kleine eenheden. Dit in tegenstelling tot de afstemming die niet bereikt wordt wanneer zij slechts twee vetrijke maaltijden nuttigen; dit blijkt gemakkelijk tot overeten te leiden $(18,19)$.

\section{Intermezzo 2: Modulerende factoren}

Een voorbeeld van een modulerend effect vanuit de omgeving is dat men bij een lage omgevingstemperatuur gat overeten $(10,12)$. Niet slechts om alan de circa $10 \%$ grotere energiebehoefte te voldoen, maar men overeet met wel $40 \%$. Daarmee blijkt men een daling van de kerntemperatuur te voorkomen. Hoe meer men overeet, des te meer het energiegebruik stijgt, des te minder de kerntemperatuur daalt. Het aldus voorkomen van daling van de kerntemperatuur bleek direct verband te houden met het door het individu waargenomen comfort van de omgeving $(10,12)$.

Omgekeerd blikt men bij een hogere temperatuur te weinig te gaan eten, niet slechts om a an de met 10\% afgenomen energiebehoefte te 
voldoen, mar men eet wel $20 \%$ te weinig. Men blijkt daarmee de stijging van de kerntemperatuur te kunnen voorkomen $\left(\mathrm{so}_{*} \mathrm{w}\right)$. Hoe minder men eet, des te meer het energiegebruik daalt, des te minder de kerntemperatuuur stijgt, hetgeen eveneens in direct verband staat met het door het individu waargenomen comfort $(10, m)$.

Een andere modulerende factor is grote hoogte; boven de 3000-5000 meter ontstaat gebrek aan eetlust. Een experiment waarin door middel van hypobare hypoxie de omstandigheden waaronder de Mt Everest beklommen wordt gesimuleerd werd, toonde aan dat zonder dat er sprake was van hoogteziekte of grote inspanning, de voedselinname spontaan wermindert (75). Onze hypothese is dat hier zuurstofgebrek een rol speelt. Het eten verhoogt het zogeheten dieetgeinduceerde energiegebruik, waardoor de zuurstofconsumptie is verhoogd. in zuurstofarme omstandigheden ontstaat dan snel een benauwd gevoel, dat aangeeft dat men niet meer tot eten in staat is en door het individu vertaald wordt in een gevoel van verzadiging. Bij toenemende hoogte werd het gebrek aan eetlust zo sterk dat daaruit woliedig het gebruikel ijke gewichtsverlies tijdens expedities, $n l 5 \mathrm{~kg}$ in 5 weken, verkläard kon worden. Overigens was dit verloren gewicht door de proefpersonen: jonge, slanke mannen, snel weer herwonnen bij terugkeer naar wat zuurstofgehalte en luchtdruk betreft normale omstandigheden (15).

\section{Integratie}

Zoals gezegd, de integratie van oorzaak, ontwikkeling en modulatie van gedrag is een zich herhalend proces, dat meestal onbewust verloopt en in gewoontevorming resulteert ( $)$.

\section{Funktie van de voedselinname}

\section{Eten om te leven}

Voedselinname heeft in de eerste plaats overlevingswaarde; men eet orn te leven. Ten dele om zichzelf te handhaven: brood en wijn wordt vees en bloed. Ten dele om met de energie die het voedsel verschaft de levensprocessen te onderhouden: de basale processen, de vertering van het woedsel, en lichamelijke aktiviteit.

Het energiegebruik dat deze processen wergt zet de toon voor de energie inname; deze zorgt voor afstemming en harmonie $25 \%$

De energiebalans, de balans tussen inname en uitgifte van energie weerspiegelt deze harmonie. De energiebalans handhaaft zich niet van 
uur tot uur: men eet vooral anticiperend, om de uitgaven van het volgende interval te kunnen overbruggen. Ook is er geen balans van dag tot dag: de mogelijkheid om bij een positieve balans de tegoeden op te slaan als reserves in de vorm van vet, orn deze bij een negatieve balans weer te mobiliseren, wordt dagelijks benut. Binnen een week is men in energiebalans, en dit weerspiegelt zich in een stabiel lichaamsgewicht met geringe, vooral aan lichamelijke aktiviteit gebonden seizoensschommetingen (13).

Eten om te leven streeft naar energetische efficientie. Hierbij dient het lichaamsgewicht minimaal op een bepaald niveau gehouden te worden, een niveau waarop het individu in een goede conditie is, en evolutionair gezien, een niveau waarop het individu in staat is om zich voort te planten, immers bij een te lalag of te hoog lichaamsgewicht neemt de vruchtbaarheid af.

Een woorbeell van deze energetische efficientie is de combinatie van eetgedrag en fysieke activiteit, zoals deze nog niet zolang geleden bij Eskimo's tijdens de winters gebruikelijk was. Zij aten juist genoeg, verlaagden hun lichaamsgewicht vrijwell anticiperend, en verlaagden hun fysieke aktiviteit. Door verlaging van hun energlegebruik via beperking van de fysieke activiteit en verlaging van het gewicht, konden ze met weinig voedsel toe: een overlevingsstrategie voor barre tijden (26). De zogeheten geremde eters passen tevens deze strategie toe: door een cognitief bepaalde lage voedselinname en laag energiegebruik handhaven zij hun lichaamsgewicht op het gewenste niveau $(27\rangle)$. Een overlevingsstrategie voor de huidige barre tijden van fast food en soft drinks.

\section{Leven om te eten}

Voedselinname kent ook een andere funktie, een belonende funktie: men leeft om te eten. Men eet graag lekker voedsel, en een ervaring met de hedonische en belonende waarde van het voedsel speelt een belangrijke rol in de voedselinname. Hier geldt dat naast prikkeling van honger- en verzadigingscentra in de hypothalamus en hersenstam, beloningscentra in de frontale hersenschors worden geprikkeld. Een niet-homeostatisch regulatie mechanisme in interaktie met de eerder aangeduide homeostatische regulatie mechanismen. Alleen honger-en verzadigingssignalen blijken niet bepalend te zin voor de woedselinname; deze kunnen worden overheerst door andere belonende signalen (1). Overheersing van het hongersignaal door een hoger, meer belonend doel treffen we aan bij de politieke hongerstaker; overheersing van het 
verzadigingssignaal bij het ondanks de verzadigde toestand nuttigen van het chocolaadje na de maaltijd, het ijsje in het park, het taartje op de verjaardag, en bij het niet ongehinderd een notenbar, oliebollenkraam, of frietentent kunnen passeren. De belonende waarde van het voedsel die de verzadigingssignalen overheerst blijkt in het bijzonder van belang te zijn bij individuen die lijden aan stress. Zij zijn gevangen in een vicieuze cirkel bestaande uit het overeten van belonende woedingsmiddelen. die in feite de stress blijken te verhogen.

Tevens zijn deze belonende funkties van toepassing in de communicatie met behulp van voedsel en drank: men nodigt elkaar uit voor de koffie, de lunch, de thee, een receptie, of een diner. Bij gebeurtenissen van levensbelang zoals geboorte, huwelijk en begrafenis krijgen bepaalde soorten voedsel zelfs een symbolische betekenis.

Ten slotte wordt in het dagelijkse leven onbewust rekening gehouden met deze belonende waarde; om verveling te woorkomen, bereidt men de welbekende gevarieerde maaltijden, waarmee de aanbevelingen in de vorm van kwaliteit en kwantiteit, zoals de werhoudingen tussen koolhydraten, vetten en eiwitten, voldoende vitaminen en mineralen, sporen.

Supernormale prikkels die zoals bekend uit de biologie bepaald gedrag stimuleren, worden ook hier gebruikt: in de keuken en in de voed. seltechnologie accentueert men kleur, vorm, geur, smaak en textuur.

\section{Evolutie van gedirag}

De aldus geschetste overlevingswaarde van de voedselinname op korte termijn, nl handhaving van de energieballans op een niveau dat een gezonde conditie waarborgt, en het verschaffen van voldoende belonende waarde, draagt bij aan de evolutionaire funktie van de voedselinname op lange termijn. Een gezonde conditie van het individu is woorwaarde voor voortplanting, het doorgeven van de genen aan de volgende generatie.

Echter, het effect van de lichaamsgewicht-regulatie en de daarvan afgeleide voedselinname-regulatie is dat deze evolutionair gezien afgestemd is op tijden en plaatsen waarbij overleving en voortplanting niet vanzelfsprekend zijn. Zo zal selectie hebben plaatsgevonden op genotypen die bijdragen alan het fenotype, de witerlijke verschijningsvorm, dat in staat is tot een grote energetische efficientie: veel voedsel binnenhalen, opslaan als onderhuids vet, en weinig uitgeven. Momenteel wordt gesuggereerd dat er in deze zin ongeveer 22 genen bekend zijn die de basis vormen voor deze efficientie. Genen die het individu in stat 
stellen tot overeten, sedentair gedrag, vetopslag, een geringe vetoxidatie en zuinigheid (28). In dit werband wordt altijd gedacht aan het directe effect van hongersnood op de levensvatbaarheid van het individu; echter bij nader inzien lijkt niet alleen de sterfte de levensvatbaarheid van de populatie negatief te beinvloeden, maar vooral het gebrek aan geboorten. Zo blijkt het seizoenseffect van de oogst in Gambia en Bangladesh, bepaald door de afwisseling van natte en droge perioden primair gerelateerd te zijn aan het geboorte-cijfer, in plaats wan aan het sterfte-ciffer. Dit geeft aan dat niet alleen eigenschappen wan toepassing in tijden wan overvloed, maar ook eigenschappen als het in slechte woedselomstandigheden nog het initiatief hebben tot emigreren, zoals bijvoorbeeld ten tijde van de lerse hongersnood na de mislukte aardappeloogst, en zich te kunnen voortplanten, geselecteerd zouden kunnen zijn (29).

Een vorm van existensialisme, evenals het werk van Giacometti (zo)?

\section{Confrontatie wan evolutie met de westerse welvartsmaatschappij}

Confrontatie van de genotypen die overeten, sedentair gedrag, vetopslag en zuinigheid faciliteren met de huidige westerse welvaartsmaatschappij vormt mamenteel een bedreiging voor de gezondheid. Selectie op efficientie doet zich gelden in de worm van bovenmatige vetopslag. Enerzijds ongewenst, vanwege ongezonde bijverschijnselen, zoals daarmee gepaard gaande ziekten bijwoorbeeld diabetus mellitus type 2 , en hart- en vaatziekten. (31). Anderzijds een vervorming die de werkelijkheid tot kunst maakt, en weelde en levensvreugd symboliseert, zoals Botero verbeeldt (3o). Oorzaken van bovenmatige vetopslag zijn zoals aangeduid gedeeltelijk genetisch bepaald, en liggen ten dele in het streven naal deze weelde, levenswreugd en welwaart, weliswaar in een stressvolle omgeving. Op een evolutionaire tijdschaal is het verschijnsel obesitas als reaktie op de westerse welvartsmaatschappij nog zeer recent, en er zijn meer generaties nodig om te kunnen waarnemen of selectie eventueel ook een andere kant op gaat. Wanneer er voldoende genetische variatie aanwezig is in de uitgangspopulatie is dat niet onmogelijk.

Dit is onlangs waargenomen bij een rups van de vlinder Plutella Xylostella die in acht generaties zodanig aangepast bleek te zijm aan een overmatig koolhydraatrijk dieet, dat deze minder vetreserves bleek aan te maken. De populatie rupsen die op de zetmeelrijke mutant van de zandraket (Arabidopsis) was gezet was na acht generaties zodanig van samenstelling veranderd, dat rupsen wier voorouders waren opgegroeid op zetmeelrijke planten minder koolhydraten als vet opsloegen dan hun 
tot dan toe normale soortgenoten. Rupsen met een aanleg om dik te worden waren blijkbaar uit de populatie geselecteerd. De onderzoekers concludeerden dat de aanmaak van vetreserves kennelijk ten koste was gegaan van de kans op nakomelingen ( 32 ).

Maar tot nu toe blijkt uit de toename in overgewicht en vetzucht in onze westerse welvaartsmaatschappi], dat overdaad nog steeds schaadt.

\section{Bedreiging van de gezondheild: overgewicht en obesitas}

Preventie en behandeling van overgewicht respectievelijk obesitas is dweilen met de kraan open. Gezoclht wordt naar energetische inefficientie, in een omgeving die energetische efficientie bevordert.

Er is dus behoefte aam een toverpil. En die is er wel, als men accepteert dat men gefopt wordt. De basis hiervan is ide nieuwe kleren van de kei. zer", of wel: niets is wat het lijkt, dat wil zeggen niets beantwoordt meer aan de associaties die men oorspronkelijk heeft gelegd. Het streven is dat men comfortabel in een negatieve energiebalans verkeert.

Men streeft naar verzadiging, of onderdrukking van hongergevoelens, hoewel men energetisch gezien 'niets' of te weing eet (33.34). Dit wordt gedaan door bijvoorbeeld vezel, dat energetisch gezien niets inhoudt aan de voeding toe te woegen (33), of een zeer eiwitrijke voeding te kiezen waardoor men zo verzadigd raakt, dat men spontaan minder gaat eten om de verzadiging op het gebruikelijke comfortabele peil te houden (34).

Wanneer men in deze situaties in een negatieve energiebalans raakt, ontstaat een lichamelijke bezuinigingsreaktie, die onderdeel is van het gebruikelijke efficientie proces. De energiestofwisseling daalt; de energieuitgifte vermindert de balans wordt minder negatief. Dit moet dus worden woorkomen, anders spannen we het paard achter de wagen.

Dit kan theoretisch worden voorkomen door gelijktijdig met de conmsumptie van het energetisch niets of te weinig de energiestofwisseling te stimuleren, bijvoorbeeld door zogeheten thermogene voeding: rode peper cafeine, groene thee, of veel eiwit te nuttigen (35-39).

Wanneer men gewicht verliest, verliest men ongeveer $2 / 3$ tot $3 / 4$ aan vetmassa en $1 / 3$ tot $1 / 4$ a an veturije massa. Omdat vooral de vetvrije massa, dwz de spieren en organen het energiegebruik bepalen, is deze massa van belang bij het streven naar het op peill houden van de energieuitgifte. Ook daaraan kan een eiwitrijke voeding bijdragen (17, 35-42).

Bij voorkeur wordt bevordering van al deze factoren: verzadiging. energiegebruik, behoud van vetvrije massa gecombineerd in een enkel 
voedingsmiddel met zogeheten multifactoriele eigenschappen zoals bijwoorbeeld eiwit.

Onderzoek toonde aan dat wanneer men tijdens het afwallen, en tijdens de gewichtsbehoud periode daarna de absolute hoeveelheid eiwit (dus het aantal grammen) in het menu constant houdt, terwijl men tijdens het afvallem bijvoorbeeld slechts $35 \%$ van de oorspronkelijke energiebehoefte consumeert en tijdens het gewichtsbehoud daarna slechts $70 \%$, men de verzadigingsgewoelens vrijwel op het oorspronkelijke niveau kan houden (17, 34.40-42), als ook de vetvrije lichaamsmassa en het daaraan gerelateerde energiegebruik. Relatief gezien is dit een hoog-eiwit dieet (het eiwit percentage kan 20-30\% bedragen), maar dit is relatief omdat de totale energie-inname verlaagd is (42); absoluut gezlen is het niet anders dan het handhaven van de oorspronkelijke eiwitinname in negatieve energiebalans.

De huidige farmacologische benadering zoekt het in middelen die de vet-absorptie verminderen, of die de beloning van woedselinname verminderen, waardoor de neiging tot overeten verminderd zou kunnen worden $(43.44)$. Het eens zo veelbelovende leptine heeft vooral de wetenschap gediend, onder andere zichtbaar aan het door deze Universiteit dit jaar uitgereikte ere-doctoraat aan Jeffrey Friedmam, een van de ontdekkers van leptine, maar heeft de overgewichtigen niet bereikt (45. 46)

Voorwaarde voor de werking van een toverpil is dat de betovering niet wordt verbroken; de toverpil werkt bijwoorbeeld niet wanneer men het recept in positieve energiebalans in plaats van in negatieve energiebalans toepast.

\section{Maar hoe loopt het sprookje af? Hoe realistisch zijn deze theorieen?}

Recent onderzoek aan deze Universiteit, uitgevoerd door Neeltje Vogels, naar gewichts behoud na gewichtsverlies mbv diverse op wetenschappelijk onderzoek berustende adviezen, wijst uit dat steeds onge. veer $15-20 \%$ van de individuen het verkregen gewicht behoudt. Niet zozeer vanwege deze adviezen, maar dankzij een geschikte genetische achtergrond van deze ten slotte succesvolie individuen, en het vermogen om tijdens het afvallen en behouden van het verkregen gewicht veturije massa te sparen en het verbreken van een zelf-opgelegd dieet te voorkomen (47, 48). Zowel gedrag, fysiologie, als een genetische achtergrond droegen hier gaan bij. Verder onderzoek aan dergelijke interakties is nodig. 
De eiwit-hypothese lijkt weelbelovend vanwege de multifactoriele funktie die deze impliceert. Verder onderzoek is nodig naar welke eiwitten of componenten daarvan specifiek aan de effecten bijdragen, en naar hoe de verzadiging, energiestofwisseling, eiwitstofwissseling en lichaamssamenstelling samenhangen, in negatieve energiebalans, maar ook wanneer deze positief dreigt te worden. Hieraan wordt door Manuela Lejeune, Natalie Luscombe, Kristel Diepvens, Astrid Smeets, Stijn Soenen, Margriet Veldhorst, Ananda Waelen, Anneke van Vught en Maarje Spetter gewerkt, woor een groot deel als samenwerking binnen het Wageningen Centre of Food Sciences/Top Institute food and Nutrition.

Theoretisch gezien is thermogene voeding het meest sprookjesach tig. Beproeving wan het realiteitgehalte daarvan, waar Kristel Diepvens, Astrid Smeets en Manuela Lejeune mee bezig zijn, behoeft meer onderzoek.

Onderzoek naar preventie en behandeling van de stress-gerelateerde vorm van overgewicht, en hier gaat het met name om de risicovolle appelvorm, staat nog in de kinderschoenen. De draagwijdte van het belonende effect van de voedselinname wordt wellicht onderschat.

Onderzoek hieraan is gestart door Femke Rutters, onder begeleiding van Arie Nieuwenhuizen, terwijl de samenwerking met psychologie en nucleaire geneeskunde zich begint af te tekenen. Ook dit onderzoek zal in de vorm van een samenwerking binnen het Wageningen Centre of Food Sciences/Top Institute Food and Nutrition verder ontwikkeld worden, door Andrea Sekulovic en Sofie Lemmens.

Kortom, zolang mensen niet als rupsen zijin, en confrontatie van genotype, fysiologie en gedrag met de westerse welvaartsmaatschappij tot een vervorming leidt die de werkelijkheid tot kunst maakt, is eten een zaak van gewicht. 


\section{Dankwoord}

Aan het einde van deze rede gekomen wil ik graag. $U$ allen bedanken woor Uw belangstelling en aanwezigheid. Met name wil ik noemen

de Stichting Wetenschapsbeoefening Universiteit Malastricht, die mijn bijzonder hoogleraarschap mogelijk maakte, op voordracht van het College van Bestuur en het Bestuur van de Faculteit der Gezondheidswetenschappen van de Universiteit Maastricht;

mijn promotoren, wijlen Professor dr Foppe Ten Hoor, en Professor dr Anton Steffens van de Rijks Universiteit Groningen. Foppe Ten Hoor verleende mij gastwrijheid aan de Universiteit Maastricht om destijds vanuit de Open Universiteit hier mijn onderzoekslijn Voedselinname-regulatie bij de mens op te zetten. Anton Steffens waarborgde mijn contacten met de Rijks Universiteit Groningen, en introduceerde mij in het internationale platrorm van Voedselinnameregulatie onderzoek, waar ik nog dagelliks van profiteer;

de capaciteitsgroep Humane Biologie, het onderzoeksinstituut NUTRIM, de Faculteitsbesturen der Gezondheidswetenschappen en Geneeskunde, binnenkort de Faculty of Health, Medicine and Life Sciences, en het onderzoeksplatform, die mij een omgeving van zowel de serieuze als de vrolijke kant van de wetenschap bieden;

de promovendi uit het verleden, en de post-docs, dr. Wilrike Pasman, dr. Chris Hukshorn, dr. Eva Kovacs, dr. Marleen Kamphuis, dr. Tanja Adam, dr. Manuela Lejeune, dr. Neeltje Vogels, dr. Kathleen Melanson, dr. Bert Benthem, dr. Natalie Luscombe, die aan inhoud en variatie in de onderzoeksiijn hebben bijgedragen;

de huidige promovendi Kristel Diepvens, Astrid Smeets, Stijn Soenen, Margriet Veldhorst, Ananda Waelen, Femke Rutters, Anneke van Vught, Rianne Ruijschop, Andrea Sekulovic, om wie het nu draat:

de technische, administratieve of analytische ondersteuning van Paul Schoffelen, Loek Wouters, Claudia Pachen, Wendy Sluijsmans, Joan Senden, Jos Stegen, Freek Bouwman, Maartje Spetter en Sofie Lemmens, zonder wie onze proeven niet mogelijk zouden zijn;

collega's, prof. dr. Klaas Westerterp, dr. Arie Nieuwenhuizen, prof dr. Ronald Mensink, prof. dr. Edwin Mariman, prof. dr. Wim Saris, prof. ar. Robert-Jan Brummer, die onderzoek of onderwijs delen en verrijken;

het Wageningen Centre of Food Sciences/Top Institute of Food and Nutrition, dat unieke onderzoeksmogelijkheden biedt; 
mijn ouders, onze familie en vrienden, die vaak van veraf belangstellend meeleefden en dat voor zover mogelijk nog steeds doen:

Klaas, Arjen en Marit, die waar dan ook er altijd zijn.

Ik heb gezegd. 


\section{Referenties}

1. Berthoud HR. Mind versus metabolism in the control of food intake and energy balance. Physiol Behav 81(5):781-93.2004.

2. Kissileff HR. Carretta IC, Geliebter A. PI-Sunyer FX Cholecystokinin and sto mach distension combine to reduce food intake in humans. Am I Physiol Regul integr Comp Physiol 285(5) R992-8,2003.

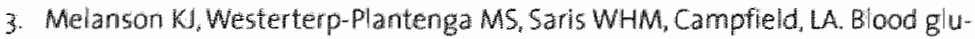
cose patterns and appetite in time-binded humans Carbohydrate versus fat. Am J Physiol Regul Integr Comp Physiol. 277:R337-45, 1999.

4. Cummings, DE Chrelin and the short-and long-term regulation of appetite and body weight. Physid Behav $30,89(1): 71-84,2006$

5. Smeets A.IPG, Westerterp-Plantenga MS Oral perception of fat and metabolic effects. Br I Nutr. Satiety and substrate mobilization after oral fat stimulation. Br Nutr. $95(4) 795$.801, 2006.

6. Adam TCM, Westerterp-Plantenga MS, GLP-1 release and satiety after a nutrient challenge in normalweight and obese subjects. Br J Nutr.93:845-5\%, 2005 .

7. Batterharm R!, Cohen MA, Ellis SM, Le Roux CW, Withers DI, Frost GS, Ghatei MA. Bloom SR. Inhibition of food intake in obese subjects by peptide M 3-36. N Engl I Med. 349(10):941-8, 2003.

8. Hinderling VB, Schrauwen P, Langhans W. Westerterp-Plantenga MS. The effect of Etomoxir on 24 h substrate oxidation and satiety in humans. Am J Clin Nutr. $76: 141-7,2002$

9. Kamphuis MMNW, Mela DM Westerterp Plantenga MS. Diacylglycerols affect substrate oxidation and appetite in humans. Am I Clin Nutr $77: 1133-9,2003$.

70. Westerterp. Plantenga MS, van Marken Lichtenbelt WD, Schrauwen P. Coreskin temperature gradient in humans related to non-shiwening thermogenesis 3. Thermal Blology 26:467-72, 2001.

11. Westerterp-Plantenga MS, van Marken Lichtenbelt WD, Cilissen C, Top 5 . Energy metabolsm in women during short exposure to an elevated ambient temperature. Physiol Behav. 75:227-35, 2002.

12. Westerterp-Plantenga MS, van Marken Lichtenbelt WD, Strobbe H, Schrauwen P. Energy metabolism in humans at allowered ambient temperature. Eur d Clin Nutil 56,288-96,2002.

13. Plasqui G, Westerterp KR. Seasonal variation in lotal energy expenditure and physical activity in Dutch young adults. Obes Res. 12(4):688-9.4.2004.

14. Westerterp KR. Energy and water balance at high altitude. News Physiol $5 \mathrm{ci}$. $16: 134-7,2001$

15. Westerterp-1antenga MS, Westerterp KR, Rubbens M, Verwegen CRT. Richalet JP. Galdette B. Appette at 'high althude' operation Everest Comex: simulated ascent of the Mt. Everest. I Appt Physiol. 87 (1): 391-9.1999.

16. Westerterp Plantenga MS verwegen CRT. The appelizing effect of an alcohol aperitif in overweight and nomal weight humans. Am J Clin Nutr. 69:205-12. 1999. 
17. Westerterp-Plantenga MS, Lejeune, MPGM, Nijs, I, van Oojen, M, Kovacs EMR. High protein intake sustains weight maintenance after weight loss in humans. Int J Obes Relat Metab Disord 28:57*64, 2004.

18. Westerterp Plantenga MS, Kovacs EMR, Melanson K. Habitual meal frequency related to blood glucose pattern, macronutient-composition and energy intake regulation in time-blinded men. Int J Obes.Relat Metab Disord. 26 : 102$10,2002$.

19. Westerterp-Plantenga MS, Goris AHC, Meijer E, Westerterp KR Habitual meal frequency in relation to resting and activity-induced anergy expenditure in human subjects: the role of fat-free mass. Br I Nutr. $90.643-4.9 .2003$

20. Westerterp-Plantenga MS. Analysis of energy density of food in relation to energy intake regulation in human subjects. Br I Nutr 85:35\%-6:, 200 :

21. Westerterp-Plantenga MS. Modulatory factors in the effect of energy density on energy intake. Br I Nutr $92: 535-9,2004$

22. Westerterp-Plantenga MS. Effects of energy density of daily food intake on long-term energy intake Physiol Behav 81:749-55,2004.

23. Westerterp-Plantenga MS. Eating behaviour in humans, characterized by cumulative food intake curves - a review. Neurosc Biobehav Rev. $24,239-48$. 2000.

24. Westerterp-Plantenga MS, Wijckmans-Dujisens NEG, Verboeket-van de Venne

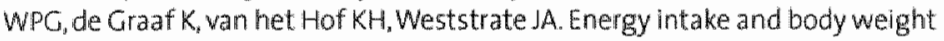
effects of six months reduced or full fat diets, as a function of dietary restraint. Int 3 Obes Rel Metab Disord. 22:14-22, 1998.

25 Westerterp.Plantenga MS. Food Intake, Metabolism and Obesity in Humans. In: The control of food and fluid intake in health and disease. Eds: M $1 \mathrm{G}$ Farthing D Mahalanabis. Nestle Nutrition Workshop series, 51, 195-221, 2003.

26. Polivy $\Downarrow$, Herman CP. An evolutionary pers pective on dieting. Appetite $47(1): 30-5$. 2006

27. Tuschl RI, Platte P, Laessle RG, Stichler W, Pirke KM. Energy expenditure and everyday eating behavior in healthy young women. Am J Clin Nutr. $52(1): 81-6$, 1990 .

28 Rankinen T, Bouchard C. Genetics of food intake and eating behavior phemoly. pes in humans. Annu Rev Nutr. 26:413-34, 2006.

29 Prentice AM. Starvation in humans: evolutionary background and conternporary implications Mech Ageing Dev 126(9):976-8?, 2005.

30 Hanstein $M$. Fernando Botero. Taschen, CmbH, Cologne, 2004.

31. Pi-Sunyer FX. The obesity epldemic: pathophysiology and consequences of obesity. Obes kes 10, $975-1045,2002$

32. Warbrick-Smith J, Behmer 5t, Lee KP, Raubenhemer D, Simpson SA. Evolwing resistance to obesity in an insect. Proc Natl Acad SCI USA. $19 ; 10348$ : $4045-9$. 2006.

33. Pasman W. Saris WH, Wauters MA, Westerterp Plantenga MS. Effect of one week of fibre supplementation on hunger and satiety ratings and energy intake Appetite $29(1) 77 \% 87,997$

34. Welgle DS, Breen PA, Matthys CC, Callahanan HS, Meeuws KE, Burden VR, Purnall 10. A high-protein diet induces sustained reductions in appetite, ad libitum 
calonc intake, and body weight despite compensatory changes in diurnal plasma leptin and ghrelin concentrations. Am I Cin Wutr. $82(1), 41-8,2005$.

35. Lejeune, MPCM, Kovacs, EMR Westerterp-Plantenga MS. Effect of capsaicin on substrate oxidation and weight maintenance after modest body weight loss in human subject. Br J Nutr. 90:651-59,2003.

36. Westerterp-Plantenga MS, lejeune MPGM, Kovacs EMR. Body weight loss and weight mairtenance in relation to habitual caffeine intake and green tea sup-

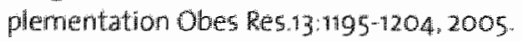

37. Westerterp-Planterga MS, Smeets A, Lejeune MPGM. Sensory and gastroin. testinal satiety effects of capsaicin on food intake. Int I Obes Relat Metab Disord. $29: 682-8,2005$.

38. Diepvens K, Westerterp KR, Westerterp-Plantenga MS Obesity aind thermogenesis related to the consumption of caffeine, ephedine, capsaicin and green tea. Am I Physiol Regui integ Comp Physiol 2006.

39. Westerterp-plantenga MS. Diepvens $K_{n}$ Joosen AMCP. Bérube Parent 5 , Tremblay A. Metabolic effects of spices, teas, and cafeine. Physiol Behaw 2006 Aug 30;89(1):85-91.2006.

40. Lejeune MPCM, Westerterp KR, Adam TC, Luscombe Marsh ND, WesterterpPlartenga MS. Ghrelin and gucagonilike peptide 1 concentrations, 24 th satiety, and energy and substrate metabolism during a high-protein diet and measured in a respiration chamber. Am J Clin Nutr. 83(1):89-94, 2006

41. Lefeune MPGM, Kovacs EMR, Westerterp Plantenga MS Additional protein intake limits weight regain after weight loss in humans. Br J Nutr 93:281.9, 2005 .

4.2. Westerterp-pantenga MS, Luscombe-Marsh $N$, Lejeune MPGM, Diepvens $K$, Niewwenhuizen A, Engelen MPKJ, Deutz NEP, Azzout-Marniche D, Tome D, Westerterp KR. Dietary protein, metabolism, and body-weight regulation: dose-response effects. Int 1 Obes Metab Disord, in press.

43. 5jostrom L. Analysis of the XENDOS study Xenical in the Prevention of Diabetes in Obese Subjects. Endocr Pract.12 Suppl 1:31-3, 2006.

44. wan Gaal LF, Peiffer, F New approaches for the management of patients with multiple cardiametabolic risk factors. I Endocinol Invest. 2913 5uppli):83-9. 2006.

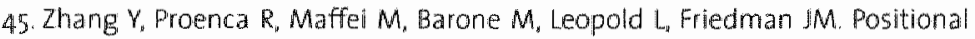
cloning of the mouse obese gene and its human homologue. Nature $372: 425$ 434.1994.

46. Westerterp Plantenga MS, Saris WH, Hukshorn CI, Camplield LA. Effects of weekly administration of pegylated recombinant human $O B$ protein on appe tite profile and energy metabolism in obese men. Am J Cin Nutr. $74(4): 426-34$. 2001.

47. Vogels N. Westerterp plantenga MS. Categarical strategies based on subject characteristics of dietary restrant and physical activity, for weight maintenance. Int 1 Obes $29: 849 \cdot 57,2005$.

48. Vogels N, Marman ECM, Bouwman FG, Diepvens K. Westerterpu Plantenga MS. Relation of weight mainkenance and detary restraint to peroxisome prolferator-activated receptor gamma2, glucoconticoid receptor, and cillary neurotrophic factor polymorphisms. Am J Clin Nutr. 82(4):740-6, 2005. 
